\title{
THE ALTITUDINAL, CLIMATICAL AND PHENOLOGICAL CLASSIFICATION OF VERBASCUM L. SPECIES FROM DIFFERENT PHYTOGEOGRAPHICAL REGIONS OF TURKEY
}

\author{
KARAVELIOGULLARI, F. A. ${ }^{1}-$ CELIK, ${ }^{2}{ }^{2}-$ ISIK, G. $^{3 *}$ \\ ${ }^{I}$ Hakkari University, Yüksekova Vocational High School, Hakkari, Turkey \\ ${ }^{2}$ Ylldiz Technical University, Faculty of Sciences, Department of Molecular Biology and \\ Genetics, Beşiktaş/İstanbul, Turkey \\ ${ }^{3}$ Anadolu University, Faculty of Sciences, Department of Biology, 26470, Eskişehir, Turkey \\ *Corresponding author \\ e-mail: glcnylmz@gmail.com \\ (fax: +902223204910$)$ \\ (Received $24^{\text {th }}$ Dec 2015; accepted $14^{\text {th }}$ Jul 2016)
}

\begin{abstract}
The Verbascum L. Group A with 4 stamens (30 taxa) were grouped which encompass ecological range, climatic specificity (temperature and precipitation), altitude and phenology (flowering and seed bearing periods) in Irano-Turanian, East Mediterranian and Euro-Siberian phytogeographical regions in Turkey. For this purpose Single Linkage (Nearest Neighbour) Hierarchical Cluster method was used. The results of cluster analyses suggested that the plant species which were collected from IranoTuranian, East Mediterranean and Euro-Siberian regions might be divided into three groups with respect to 5 characteristics based on cophenetic correlation, Delta coefficient, the pooled standard deviation of all the variables forming the cluster (RMSSTD) and determination coefficient $\left(\mathrm{R}^{2}\right)$. Pearson correlations were also computed in order to investigate linear relations between the phenological characteristics of regions. It was observed that there was a negative relation between temperature and flowering time $(\mathrm{r}=-$ 0.678; $\mathrm{p}=0.008)$, temperature and seed bearing time $(\mathrm{r}=-0.657 ; \mathrm{p}=0.011)$ in Irano-Turanian region. However, the correlation between temperature and flowering time $(\mathrm{r}=-0.096 ; \mathrm{p}=0.767)$ and temperature and seeding time $(\mathrm{r}=0.176 ; \mathrm{p}=0.584)$ was not statistically significant for the East-Mediterranean region.

Keywords: distribution, ecology, phenology, temperature, Verbascum
\end{abstract}

\section{Introduction}

Plant phenology is relevant to plant growth and reproduction. Phenological changes differ from species to species (Crick et al., 1997; Schwartz et al., 2000). Climate sets the limits for biota and all phenological changes in plants highly correlated with temperature changes (Jenny, 1941; Peñuelas et al., 2001). During the past several decades especially from the late 1970's, records of phenological changes for both plants and animals are being used for quantifying the response of biota to recent climate change (David et al., 2005; Schwartz, 1999; Abu-Asab et al., 2001; Peñuelas et al., 2001; Walter, 2002; Parmesan, 2003). Climate policy includes agriculture and food production, land use, energetics, industry and transport, environmental and nature conservation and public health, but it also has sociological, educational, communication aspects (Eppich et al., 2009). The most sensitive indicators of the effects of the climatic changes are phenological processes of the biota (Ferenczy et al., 2010). Phenological recording is a potential source for monitoring of climate change (Sparks et al., 2000).

The interaction between genetic and environmental factors such as rainfall and temperature determine the flowering period of plants (Cenci and Ceschina, 2000), 
which leads to seed bearing. Climate warming is expected to alter seasonal biological phenomena such as plant growth and flowering which depend on temperature, that is, the total heat required for an organism to develop from one point to another in its life cycle (Peñuelas et al., 2001). One of the determinants of the temperature is the altitude so it also plays an important role on the changes of phenology. Alba and Hufbauer (2012) found out that introduced $V$. thapsus populations often perform better than their native conspecifics for biogeographic data describing performance.

Turkey has an extremely rich flora due to its geographical position, ecological and climatic diversity. Turkey is located at the connection of 3 phytogeographical regions; Irano-Turanian, East Mediterranean and Euro-Siberian (Figure 1). It was estimated that there were 9000 plant taxa naturally distributed in Turkey and 30\% of them are endemic (Taskin, 2000; Ekim et al., 2001).

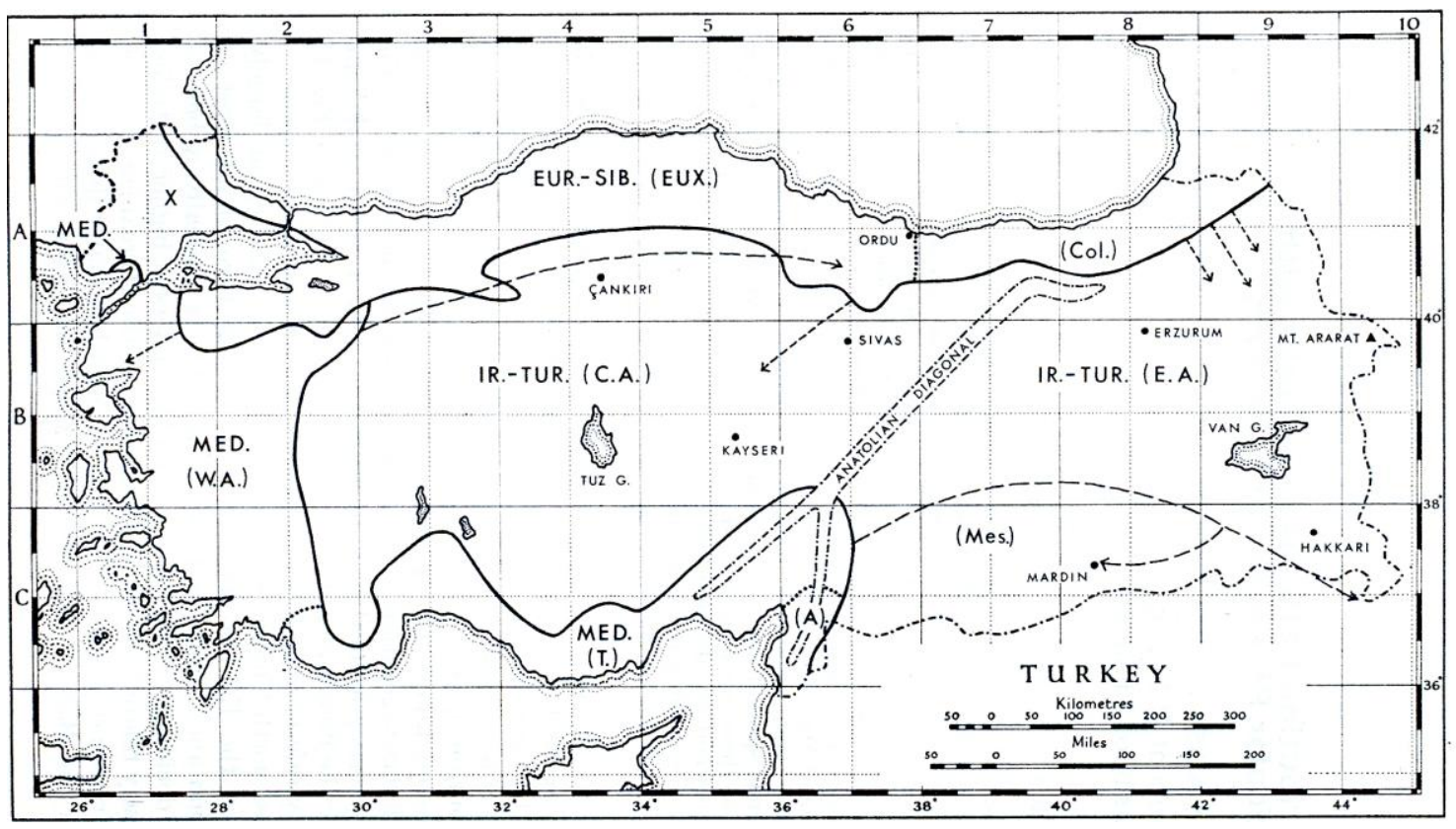

Figure 1. The phytogeographical regions in Turkey

Scrophulariaceae family comprises 280 genera and 3000 species in the world and 30 genera and 466 species in Turkey. Genus Verbascum is represented by 360 taxa in the world and by 234 taxa in Turkey (Vural and Aydogdu, 1993; Karaveliogullari et al., 2004). Endemism of the genus in Turkey is very high with 196 endemic species (80\%) (Cecen et al., 2015; Karavelioğulları, 2012, 2014a, 2014b). Verbascum group A, which has been revised, could be easily distinguished from the other Verbascum groups with having 4 stamens. In Turkey, its neighboring countries and Europe, there are 45 Verbascum species with 4 stamens. General distribution of the Verbascum species with 4 stamens is given in Table 1 and Figure 2. (Huber-Morath, 1973, 1974, 1978, 1981; Meikle, 1985). The genus Verbascum includes species that grow in different habitats, such as sandy places, rocks, open and semi-open natural habitats (Catara et al., 2016). 


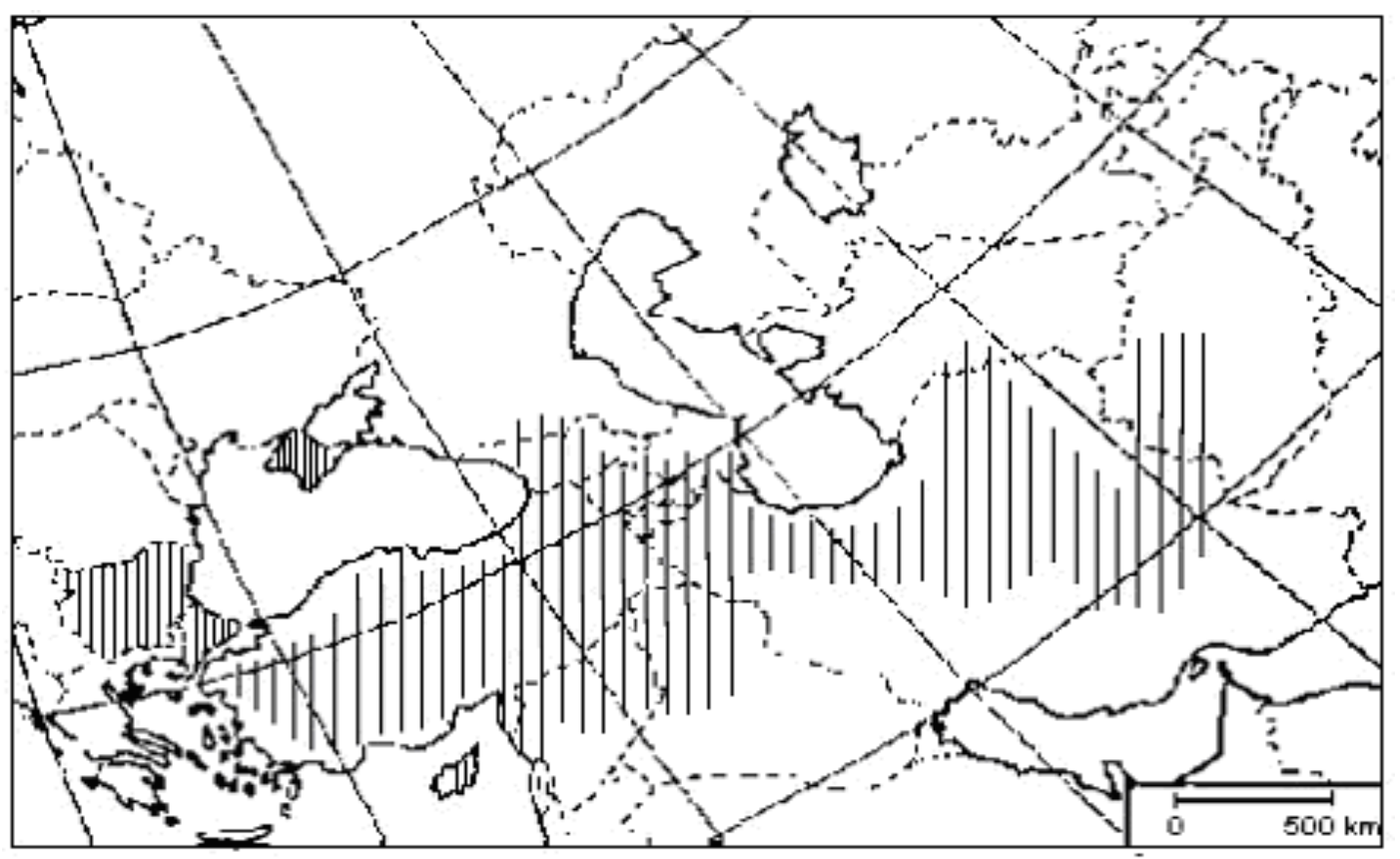

Figure 2. Distribution of Verbascum Group A taxa in Turkey and neighboring countries.

Table 1. Comparison of number of species belonging to genus Verbascum, group A and the number of endemic species from Turkey and neighboring countries.

\begin{tabular}{|c|c|c|c|c|c|c|}
\hline $\begin{array}{c}\text { Countries / } \\
\text { Regions }\end{array}$ & Turkey & Europe & Russia & Iran & Palestine & Cyprus \\
\hline Total taxa & 234 & 99 & 51 & 49 & 20 & 6 \\
\hline $\begin{array}{c}\text { Taxa with 4 } \\
\text { stamen }\end{array}$ & 25 & 17 & 5 & 18 & 5 & 2 \\
\hline Endemic taxa & 17 & - & - & 10 & - & - \\
\hline
\end{tabular}

As seen in Table 1, when we compare with other countries and Europe, Turkey is rich for taxa of Verbascum genus and species with 4 stamens. Turkey is a rich center and most appropriate for solving taxonomic problems related to this genus.

Although the taxa found in group A are distributed in all regions of Turkey, they are localized especially in the Mediterranean and East Anatolia regions. Genus Verbascum Group A is represented by 30 taxa in the Flora of Turkey, 11 members of them are Irano-Turanian, 12 are Mediterranean and 4 of them are Euro-Siberian element (Karaveliogulları and Aytac, 2008).

The species of Verbascum genus group A belongs to Irano-Turanian, East Mediterranean and Euro-Siberian phytogeographical regions according to their distribution dominance respectively. Especially, although there are some transitions between Irano-Turanian and East Mediterranean regions, in this study, the phytogeographical regions in which the species density is high because of its origin were taken into account (Table 2, Figure 3, 4, 5, 6). 
Table 2. The list of Verbascum taxa; including origin, life form and habitat characteristics of collection sites.

\begin{tabular}{|c|c|c|c|}
\hline Species & Origin & Region & Habitat Characteristics \\
\hline V. natolicum & Turkey, Russia & Irano-Turanian & Steppe and Stony slopes \\
\hline V. spodiotrichum & Turkey & E.Mediterranean & Forest and Limestone rocky \\
\hline V. orientale & Balkans,Crimean,Syria,Lebanon Palestina,Iraq & E. Mediterranean & Steppe and Stony place \\
\hline V. orientale & Turkey & E.Mediterranean & Steppe and Pebble slopes \\
\hline V. cilicicum & Turkey & Irano-Turanian & Steppe and Volcanic rocky \\
\hline V. flabellifolium & Turkey & E.Mediterranean & Steppe and Serpentine rocks \\
\hline V. trapifolium & Turkey & E.Mediterranean & Steppe and Serpentine rocks \\
\hline V. pyroliforme & Turkey & Irano-Turanian & Steppe and Salty marshes \\
\hline V. dudleyanum & Turkey & Irano-Turanian & Steppe and Wet places \\
\hline V. coronopifolium & Turkey & Irano-Turanian & Forest and Rocky mountain slopes \\
\hline V. serratifolium & Turkey & Irano-Turanian & Steppe and Serpentine rocks \\
\hline V. basivelatum & Turkey & Irano-Turanian & Steppe and Serpantine rocks \\
\hline V. bourgeauanum & Turkey & E.Mediterranean & Steppe and Alpine slopes \\
\hline V. serpenticola & Turkey & E.Mediterranean & Steppe and Serpentine rocks, \\
\hline V. sorgerae & Turkey & E.Mediterranean & Juniperus and Cedrus and Juniperus \\
\hline V. nudicaule & Turkey, Iran & Irano-Turanian & Steppe and Serpentine rocks \\
\hline V.suworowianum var. suworowianum & Turkey, Iran & Irano-Turanian & Steppe and Pebble place \\
\hline V. suworowianum var. papilloseum & Turkey, Iran & Irano-Turanian & Steppe and Volcanic tuff \\
\hline V. luciliae & Turkey & E.Mediterranean & Steppe and Volcanic slopes \\
\hline V. rupicola & Turkey & E.Mediterranean & Forest and Rocks \\
\hline V.agrimoniifolium subsp. & Turkey, Iraq, Iran, Afghanistan & Irano-Turanian & Steppe and Riversides wet places \\
\hline V. levanticum & Turkey,Cyprus, Lebanon, & E.Mediterranean & Maquis and Limestone rocky place \\
\hline V. bugulifolium & Turkey, Bulgaria & Euro-Siberian & Forest and Longoz forest \\
\hline V. ponticum & Turkey & Euro-Siberian & Steppe and Meadows \\
\hline V. bornmuellerianum & Turkey, Iraq & Irano-Turanian & Steppe and Limestone slope \\
\hline V. oreophyllum var. oreophyllum & Turkey, Russia & Irano-Turanian & Steppe and Meadow, \\
\hline V. oreophyllum var. joannis & Turkey, Iran, Iraq, Lebanon & Irano-Turanian & Steppe and Meadow, \\
\hline V. gaillardotii & Turkey, Syria, Lebanon, Filistin & E.Mediterranean & Maquis and Limenstone slopes \\
\hline V. freynii & Turkey & Euro-Siberian & Steppe and Waste places \\
\hline V. transcaucasicum & Turkey, Russia & Euro-Siberian & Steppe and Rocky damp places \\
\hline
\end{tabular}




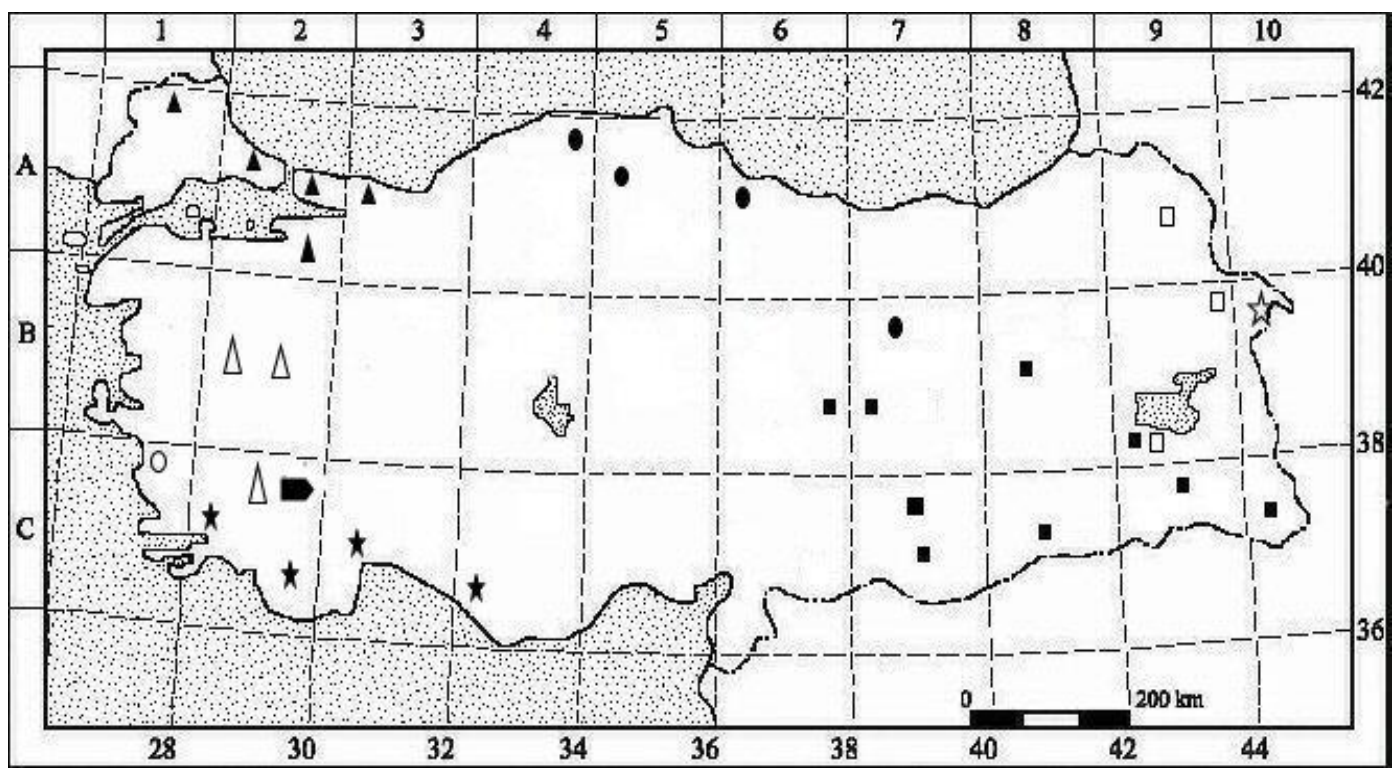

Figure 3. Distribution of Verbascum taxa in Turkey (ם)V. agrimoniifolium subsp.

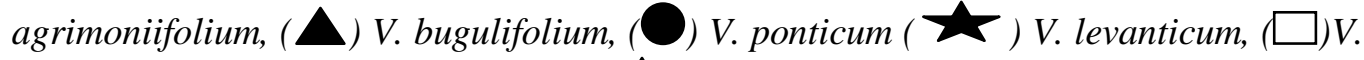
Suworowianum var. suworowianum, ( $\left.\Sigma^{3}\right)$. suworowianum var. papillosum, $(\Delta) V$. luciliae, $(\bigcirc)$ V. rupicola, $(\mathbf{D})$

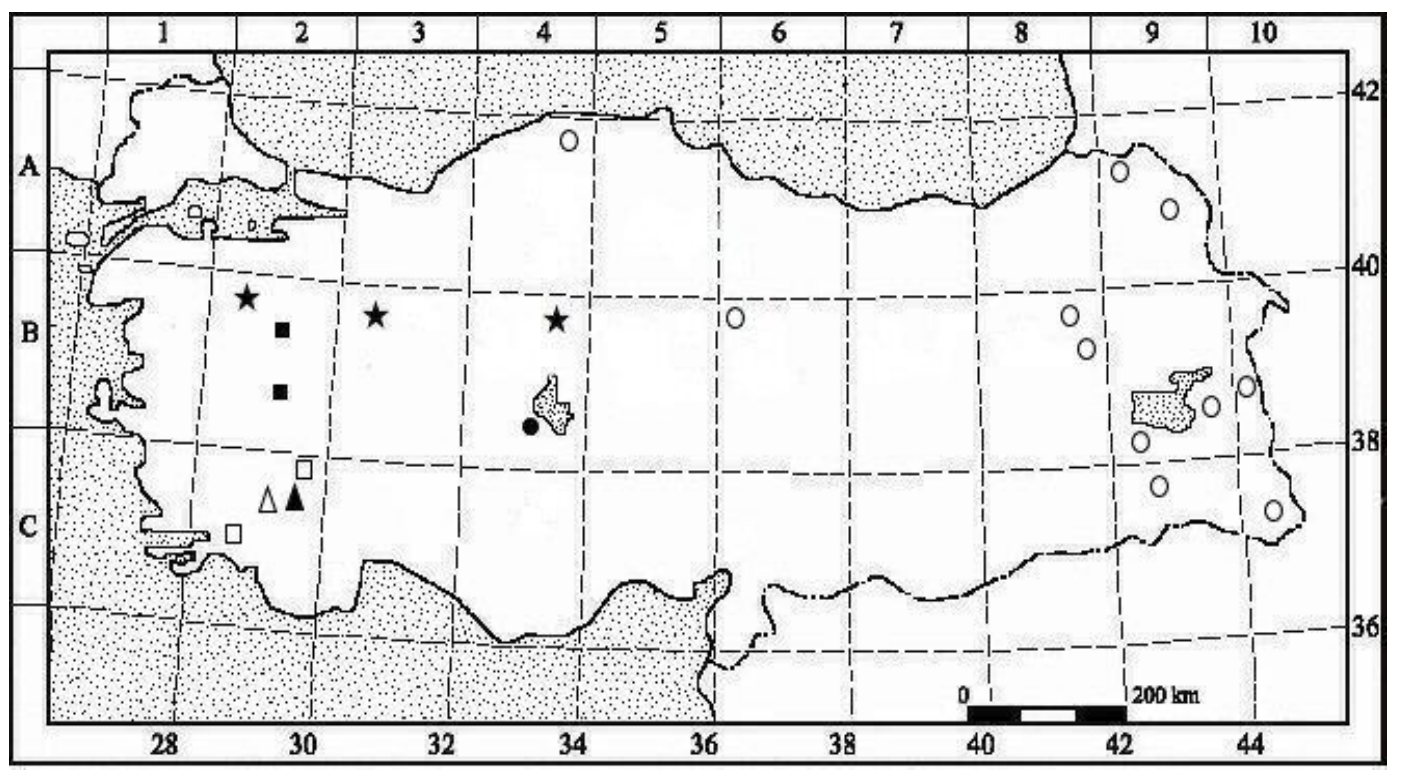

Figure 4. Distribution of Verbascum in Turkey $(\mathbf{\square})$ V. coronopifolium, ( $\mathbf{\Delta})$ V. dudleyanum, () V. pyroliforme $(\boldsymbol{\sim})$ ) V. serratifolium, $(\square)$ V. trapifolium, $(\triangle)$ V. flabellifolium, $(\bigcirc) V$. oreophilum var. oreophilum 


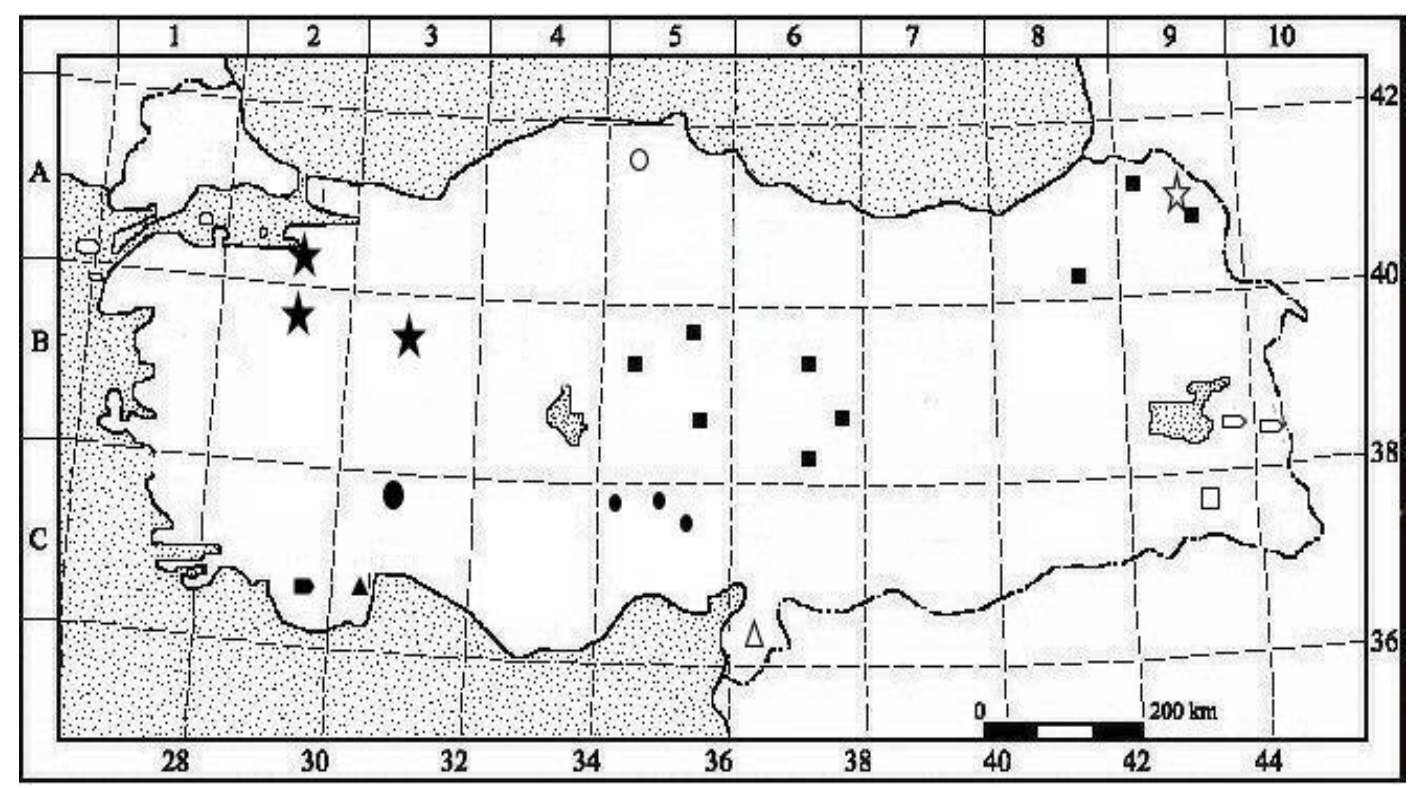

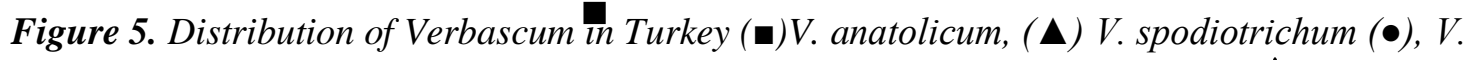
cilicium, $(\square) V$. bornmuellerianum, $(\triangle)$ V. gaillardotii, $(\bigcirc)$ V. freynii, $(\uparrow) V$. transcaucasicum, ( $)$ ) V. basivelatum, ( V. sorgerae, (D) V. bourgeauanum, $(\square) V$. nudicaule

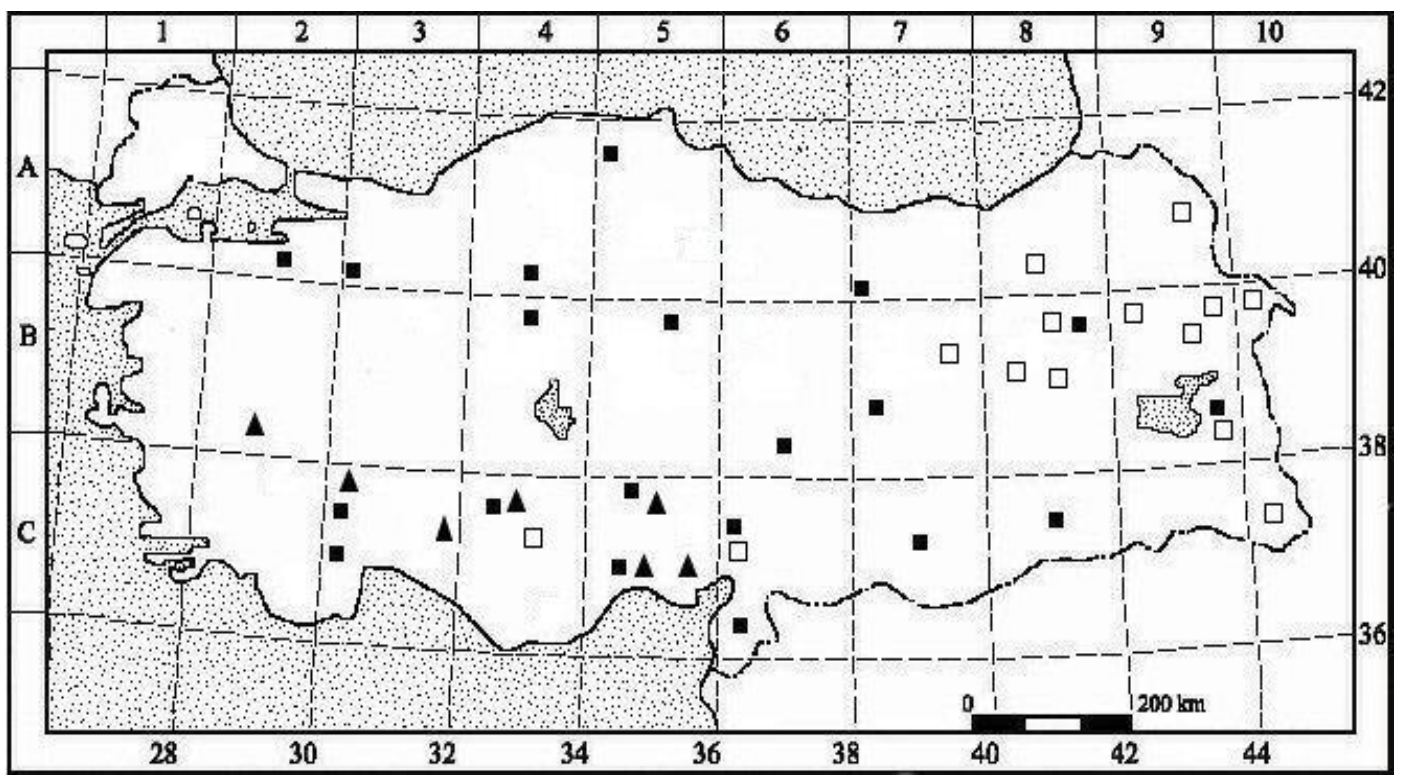

Figure 6. Distribution of Verbascum taxa in Turkey $(\mathbf{\square})$. orientale, ( $\mathbf{\Delta}) \mathrm{V}$. brachysepalum, $(\square)$ V. oreophilum var. joannis

\section{Materials and Methods}

All the taxa of Verbascum Group A were collected at their flowering and seed bearing periods from May to September between 2001 and 2003. Identification of these specimens were done according to Flora of Turkey (Davis, 1988) and also the type specimens of these specimens or their photos in different herbaria; AEF, ANK, 
EGE, GAZI, HUB, ISTF, KNYA, VANF G, GB, P, K, B, were investigated. In addition to Rabinowitz's rarity criteria the threaten categories were examined and re-evaluated according to IUCN and field observations (IUCN 2001; Ekim et al., 2001). The Verbascum Group A (with 4 stamens) were grouped which encompass ecological range, climatic specificity, altitude and vegetative period (flowering and seed bearing).

The Single Linkage (Nearest Neighbour) Hierarchical Clustering was used to group the taxa from Irano-Turanian, East Mediterranean and Euro-Siberian phytogeographical regions according to their ecological, climatological and phenological characteristics. All the measurements and data were standardized to avoid influences of different measurement units. $\mathrm{R}^{2}$ (determination coefficient), RMSSTD (the pooled standard deviation of all the variables forming the cluster), Cophenetic Correlation coefficient (this is the Pearson correlation between the actual distances and the predicted distances based on this particular hierarchical configuration) were used as goodness of fit criteria for clustering. A value of 0.75 or above needs to be achieved in order to consider clustering statistically meaningful and Delta (values close to zero are desirable) were used (Sharma, 1996; Anonymous, 2005). In analyzing the data set NCSS for windows, SAS and Minitab for windows (version 13.0) statistical package programs were used.

\section{Results and Discussion}

Verbascum Group A which comprises the taxa that have 4 stamens are spreading all over Turkey. Competition and environmental conditions determine the limits of the distribution of these taxa. The descriptive statistics of altitude, climatic parameters (temperature and precipitation) and phonological characteristics (flowering and seed bearing periods) in phytogeographical regions can be seen in Table 3 .

Table 3. Descriptive Statistics with Phytogeographical Area

\begin{tabular}{|c|c|c|c|}
\hline & \multicolumn{3}{|c|}{ Phytogeographical Area } \\
\cline { 2 - 4 } & Irano-Turanian & East Mediterranian & Euro-Siberian \\
\hline Variables & $\overline{\mathrm{X}} \pm \mathrm{S}_{\overline{\mathrm{X}}}$ & $\overline{\mathrm{X}} \pm \mathrm{S}_{\overline{\mathrm{X}}}$ & $\overline{\mathrm{X}} \pm \mathrm{S}_{\overline{\mathrm{X}}}$ \\
\hline Altitude (m.) & $1415.8 \pm 85.8$ & $756 \pm 102$ & $633 \pm 313$ \\
\hline Temperature $\left({ }^{\circ} \mathrm{C}\right)$ & $9.35 \pm 0.35$ & $15.4 \pm 0.85$ & $11.2 \pm 1.43$ \\
\hline Rain (mm) & $429.4 \pm 21.1$ & $719.5 \pm 68.5$ & $555.6 \pm 33.6$ \\
\hline Flowering (month) & $6.4 \pm 0.11$ & $5.5 \pm 0.16$ & $5.6 \pm 0.33$ \\
\hline Seed bearing (month) & $7.4 \pm 0.14$ & $6.6 \pm 0.16$ & $6.2 \pm 0.36$ \\
\hline
\end{tabular}

The results of clustering for Irano-Turanian phytogeographical region were given in Figure 7. According to the cluster analysis V. serratifolium (Hub.-Mor.) Hub.Mor. and V. dudleyanum (Hub.-Mor.) Hub.-Mor. are joined by the horizontal line that intersected the distance axis at the value of approximately 0,45. This situation indicates that these two species are closely related with each other than the others. This is also true for $V$. basivelatum Hub.-Mor. and $V$. suworowianum var. suworovianum (C.Koch) O.Kuntze; V. suworowianum var. papilloseum (C.Koch) 
O.Kuntze and $V$. orephilum C. Koch var. joannis (Bordz.) Hub.-Mor. There is an obvious outlier; $V$. agrimoniifolium (C. Koch) Hub.-Mor. In Irano-Turanian phytogeographical region there are three obvious clusters; the first one is $V$. serratifolium, V. dudleyanum, V. anatolicum Somrn. \& Lev., V. pyroliforme (Boiss. \& Heldr.) O.Kuntze, V. cilicicum Boiss., V. bornmuellerianum Hub.-Mor., $V$. coronopifolium (Boiss. \&Bal.) O. Kuntze; the second one is $V$. basivelatum, $V$. suworowianum var. suworowianum and V. nudicaule (Wydler) Takht., and the last cluster is $V$. suworowianum var. papilloseum, $V$. oreophilum var. oreophilum, $V$. oreophilum var. joannis and V. agrimoniifolium (Table 4 and Figure 7). The most similar species are $V$. serratifolium and $V$. dudleyanum pair and $V$. anatolicum. The species most different from the others is $V$. agrimoniifolium subsp. agrimoniifolium, because it merges with others at a relatively high dissimilarity of 0,92 . Generally, in the separation of plant taxa from this phytogeographical region in 3 groups, the cophenetic correlation was measured as 0,79 , Delta $(0,5)$ as 0,56 and $R^{2}$ as 0,80 from the measurements of the success of grouping or the goodness of fit. Hence it can be suggested that grouping of these 14 taxa with respect to these 5 characteristics is appropriate.

The species of third cluster which are $V$. suworowianum var. papilloseum, $V$. oreophilum var. oreophilum, $V$. oreophilum var. joannis and V. agrimoniifolium are more similar to each other than the species belong to first and second clusters $(\mathrm{RMSSTD}=0,358)$ (Table 4).

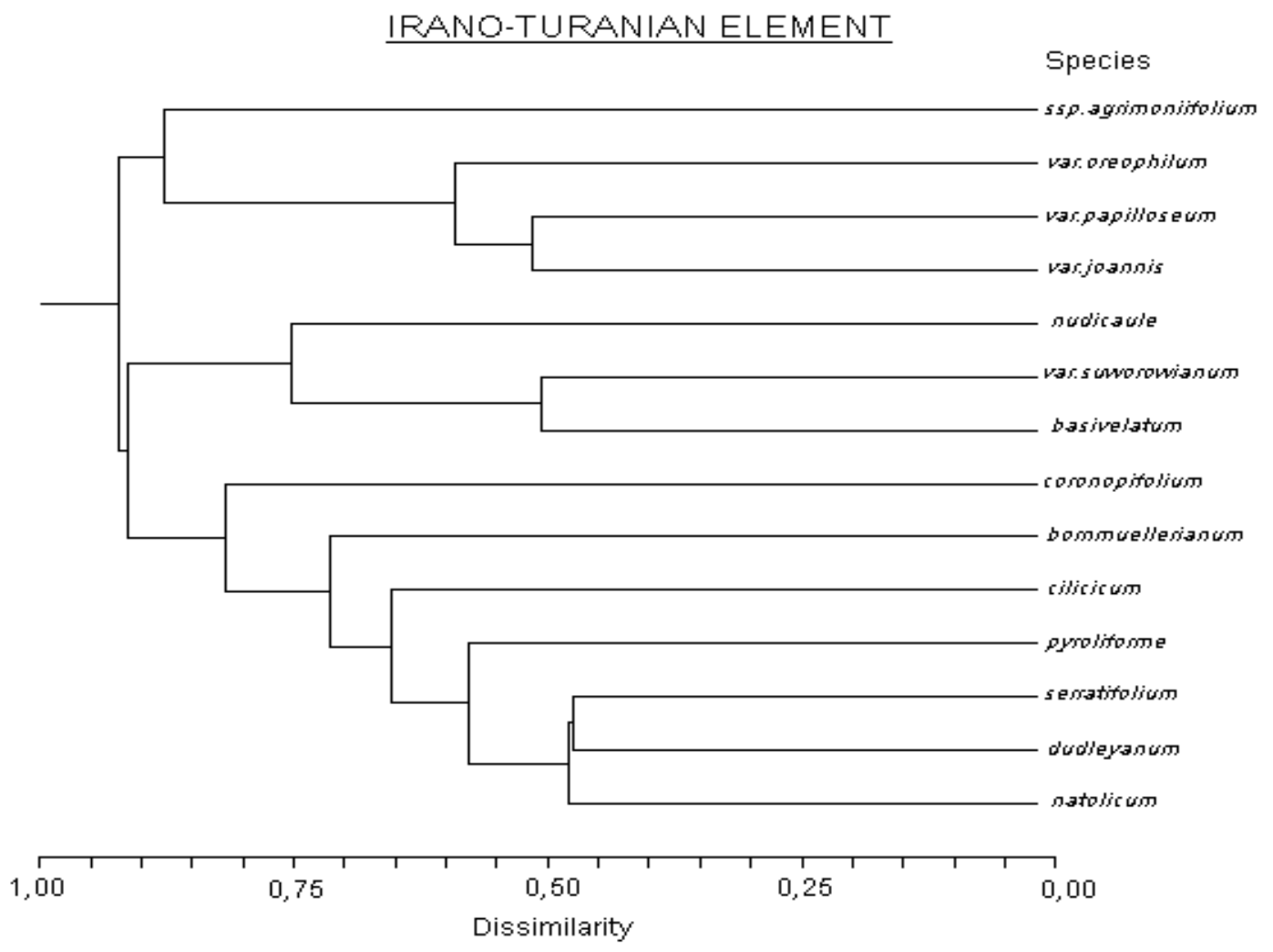

Figure 7. Clusters dendrogram for Irano-Turanian Region 
Table 4. The Summary of Clustering

\begin{tabular}{|c|c|c|c|c|c|}
\hline \multicolumn{6}{|c|}{ Irano-Turanian Phytogeographical Region } \\
\hline Cluster & Frequency & RMSSTD* & $\begin{array}{c}\text { Overall } \\
\mathrm{R}^{2 * *}\end{array}$ & F Statistics & $\begin{array}{l}\text { Cophenetic } \\
\text { Correlation }\end{array}$ \\
\hline 1 & 7 & 0.589 & \multirow{4}{*}{0.80} & \multirow{4}{*}{9.12} & \multirow{4}{*}{0.78} \\
\hline 2 & 3 & 0.426 & & & \\
\hline \multirow[t]{2}{*}{3} & 3 & 0.358 & & & \\
\hline & 1 & - & & & \\
\hline \multicolumn{6}{|c|}{ East-Mediterranean Phytogeographical Region } \\
\hline 1 & 3 & 0.629 & \multirow{3}{*}{0.79} & \multirow{3}{*}{6.42} & \multirow{3}{*}{0.82} \\
\hline 2 & 7 & 0.511 & & & \\
\hline 3 & 2 & 0.677 & & & \\
\hline
\end{tabular}

*RMSSTD is the pooled standard deviation of all the variables forming the cluster. The smaller the value, the more homogenous the observations are with respect to the variables and vice versa. $* \mathrm{R}^{2}$ measures extent to which groups or clusters are different from each other. Alternatively, one can say it also measures extent to which the groups are homogenous.

The cluster analysis results for East Mediterranean phytogeographical region was given in Figure 8. V. spodiotrichum (Hub.-Mor.) Hub.-Mor. and V. rupicola (Hayek \& Siehe) Hub.-Mor. were joined by the horizontal line that intersected the distance axis at a value of approximately 0,72 , which indicates that these are the most similar species in this phytogeographical region. The pairs $V$. orientale (L.) All. and V. brachysepalum (Fisch. \&Trautv.) O. Kuntze, V. trapifolium (Stapf) Hub.-Mor. and V. serpanticola (Stapf) Hub.-Mor., and V. bourgeauanum Hub.-Mor. and V. gaillardotii Boiss. are more similar to each other than the others. V. bourgeauanum and V. gaillardotii is the pair that is most dissimilar to the others and the outliers with the dissimilarity value of 1,28. There are 3 obvious clusters; first one is $V$. bourgeauanum, V. gaillardotii, the second one is $V$. orientale, $V$. brachysepalum, $V$. flabellifolium (Hub.-Mor.) Hub.-Mor., $V$. trapifolium V. serpenticola, V. sorgerae (Hub.-Mor.) Hub.-Mor., V. luciliae (Boiss.) O. Kuntze and the third one is $V$. spodiotrichum, $V$. rupicola and $V$. levanticum I. K. Ferguson (Table 4, Figure 8). Generally, in separation of plant specimens collected from this region in three groups, the cophenetic correlation was found as 0,82 and Delta $(0,5)$ as 0,33 , and $R^{2}$ as 0,79 from the measurements of the success of grouping or the goodness of fit. A high value for $\mathrm{R}^{2}$ indicates that the clusters are well separated and consequently the clusters are quite homogenous.

There are 4 species from Euro-Siberian phytogeographical region. According to the cluster analysis the most similar species are V. freynii (Sint.) Murb. and V. ponticum (Boiss.) O.Kuntze, the dissimilarity value of these two species was found as 0,75 . There were 3 clusters found for Euro-Siberian phytogeographical region. V. transcaucasium Wulf is the most different from the others (Figure 9).

The summary of the statistics for evaluation of cluster solution was given in Table 4 . From Table 4 it appears that there are three clusters in the data set. Furthermore, the three clusters are well separated suggested by $\mathrm{R}^{2}$, and the clusters are homogenous as evidenced by the low value of RMSSTD. 


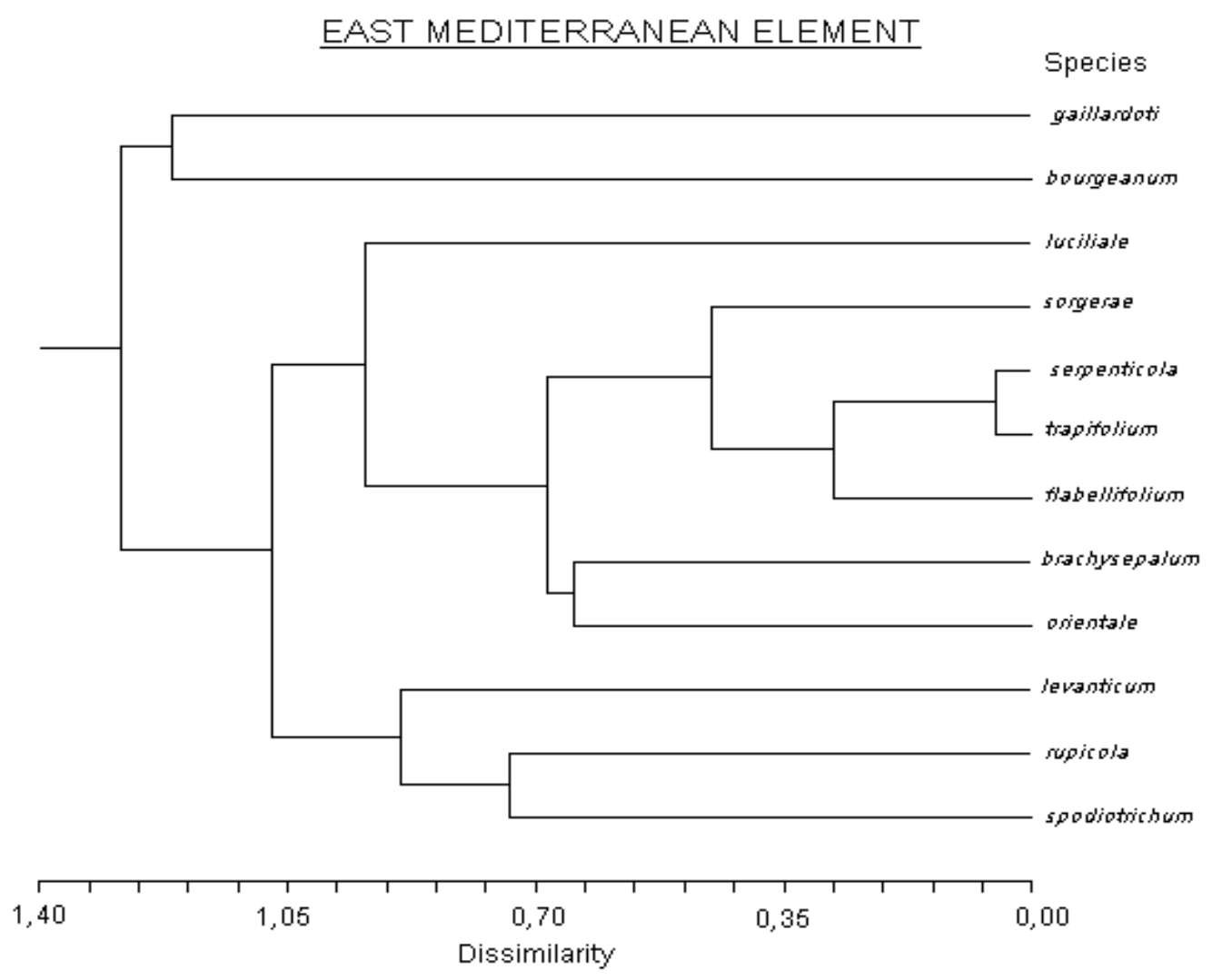

Figure 8. The Cluster dendrograme for East Mediterranean Region

\section{EURO-SIBERIAN ELEMENT}

Species

transcaucasicum
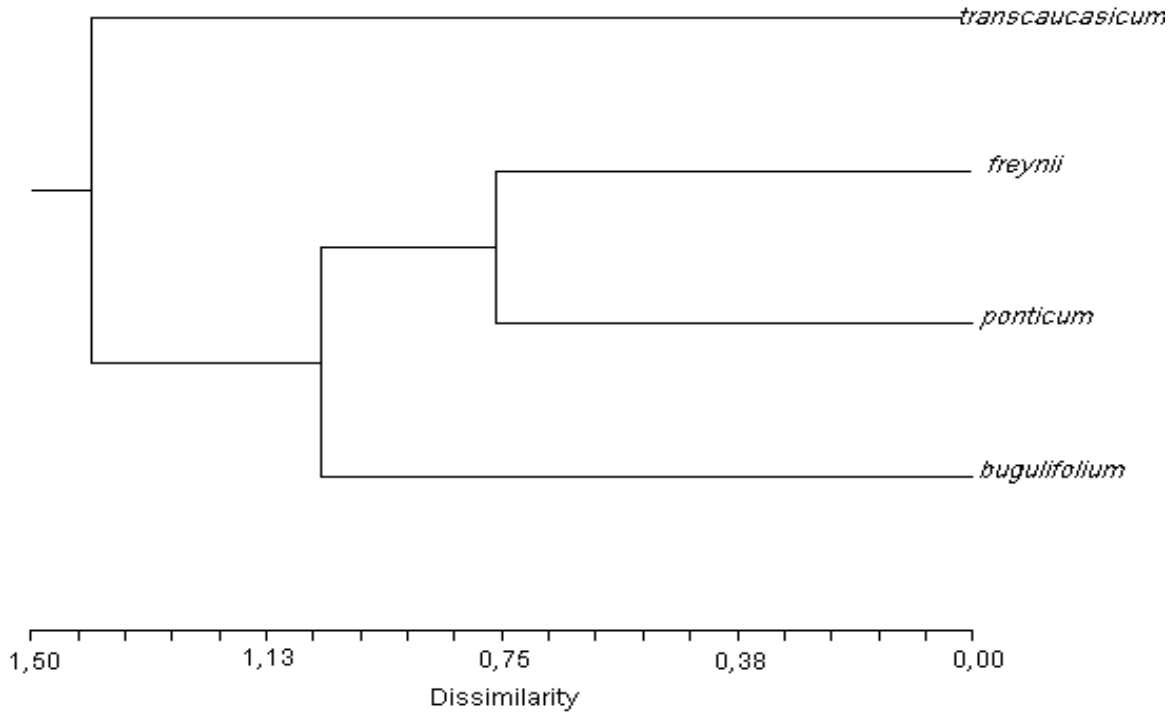

Figure 9. The Cluster dendogram for Euro-Siberian Region 
The correlations between mean annual temperatures, altitude, mean annual precipitation of localities from where the plant species were collected and the flowering and seed bearing periods can be seen from Table 5. For Irano-Turanian phytogeographical region there is a negative linear correlation between temperature and both flowering $(\mathrm{r}=-0,678, \mathrm{P}=0,08)$ and seed bearing $(\mathrm{r}=-0,657, \mathrm{P}=0,011)$ periods. There is also negative linear correlation between precipitation and both flowering $(\mathrm{r}=-0,465$, $\mathrm{P}=0,094)$ and seed bearing $(\mathrm{r}=-0,534, \mathrm{P}=0,055)$. On the other hand there is a positive linear correlation between altitude and both flowering $(\mathrm{r}=0,413, \mathrm{P}=0,142)$ and seed bearing $(\mathrm{r}=0,460, \mathrm{P}=0,098)$ periods. These results confirmed that if the temperature increases the flowering and seed bearing periods become earlier.

When the correlation between, mean annual temperature, altitude, mean annual precipitation of the localities from where these 12 plants were collected at EastMediterranean region, and the flowering and fruiting periods of these plant species were investigated, it was found that; temperature has a poor negative correlation with flowering time $(\mathrm{r}=-0,096, \mathrm{R}=0,767)$ and positive correlation with seedling time $(\mathrm{r}=0,176, \mathrm{P}=0,584)$. There was a positive correlation between precipitation and flowering $(r=0,077, P=0,813)$ and seedling time $(r=0,47, P=0,123)$. On the other hand, although there was a poor negative linear correlation between altitude and seedling time $(\mathrm{r}=-0,180, \mathrm{P}=0,577)$, there was a poor positive correlation between altitude and flowering time ( $\mathrm{r}=0,147, \mathrm{P}=0,649)$ (Table 5).

Table 5. Pearson Correlations between the variables and Phytogeographical Regions

\begin{tabular}{|c|c|c|c|c|c|}
\hline $\begin{array}{c}\text { Phytogeographical } \\
\text { Region }\end{array}$ & Variable & Temperature & Precipitation & Altitude & Flowering \\
\hline \multirow{4}{*}{ Irano-Turanian } & Rain (mm) & 0.643 & & & \\
\hline & Altitude (m) & -0.667 & -0.710 & & \\
\hline & $\begin{array}{l}\text { Flowering } \\
\text { (month) }\end{array}$ & -0.678 & -0.465 & 0.413 & \\
\hline & $\begin{array}{l}\text { Seed bearing } \\
\text { (month) }\end{array}$ & -0.657 & -0.524 & 0.460 & 0.926 \\
\hline \multirow{4}{*}{ E. Mediterranean } & Rain (mm) & 0.806 & & & \\
\hline & Altitude (m) & -0.652 & -0.579 & & \\
\hline & $\begin{array}{c}\text { Flowering } \\
\text { (month) }\end{array}$ & -0.096 & 0.077 & 0.147 & \\
\hline & $\begin{array}{l}\text { Seed bearing } \\
\text { (month) }\end{array}$ & 0.176 & 0.470 & -0.180 & 0.693 \\
\hline
\end{tabular}

Baltzoi et al. (2015) reported that $V$. olympicum is one of the drought tolerant suggested species which is recommended for Mediterranean gardens. Group A species have also been used as ornamental plants for ecologically suitable areas. Gabriele et al. (2014) determined the potential effects of climate change on 22 plant species whose range is restricted to central-northern Mediterranean region and one of these species was $V$. conocarpum which lives between $0-1800 \mathrm{~m}$ altitudes and geographically restricted in several habitats. Gabriele et al. (2014) also emphasize the need of monitoring and conservation actions immediately and suggest that rare species might be useful for monitoring the effects of global warming in the Mediterranean region. Verbascum (Group A) species, mentioned in this study, have importance to monitoring the climatic issues for Mediterranean, Euro-Siberian and Irano-Turanian regions. Motamedi and 
Souri (2016) V. stachydiforme is under intense grazing threat and its communities have confidential degree of resilience that can self-restored to its original state. In Turkey, grazing is a big problem of Irano-Turanian region especially, but self-restoring capability of Verbascum species shows the importance of weeds in terms of vegetation durability. Nagase et al. (2013) found out that $V$. phoeniceum and other 53 species were used to build a green roof and just 9 species were grown, $V$. phoeniceum was not one of them. Suchkova et al. (2014) reported that V. undulatum could be classified as heavy metals hyper accumulator and Wójcik et al., (2014) determined that V. phlomoides potentially suitable for biomonitoring and phytoremediation. It seems Verbascum species was appropriate for monitoring climatic change in natural habitats, not in urban habitats, although some of them have surviving capacity for polluted areas. Petanidou et al. (2014) determined that annual plant species were much more affected than perennials from phenological shifts. This may clarify the ability of perennial Verbascum species against climatic changes.

\section{REFERENCES}

[1] Abu-Asab, M., Peterson, P.M., Shetler, S.G., Orli, S.S. (2001): Earlier plant flowering in spring as a response to global warming in the Washington, D.C., area.- Biodivers Conserv 10:597-612.

[2] Alba, C., Hufbauer, R. (2012): Exploring the potential for climatic factors, herbivory, and co-occurring vegetation to shape performance in native and introduced populations of Verbascum Thapsus - Biol Invasions (2012) 14:2505-2518.

[3] Anonymous, Free Updates for NCSS 2004 and PASS 2005 - May 6, 2005 Release manual that quickly acquaints you with the basics of using NCSS and PASS. www.ncss.com/download.html

[4] Baltzoi, P. et al. (2015): Low water-demand plants for landscaping and agricultural cultivations - a review regarding local species of Epirus/Greece and Apulia/Italy Agriculture and Agricultural Science Procedia 4: 250 - 260.

[5] Brummitt, R.K., Powell, C.E. (1992): Authors of Plant Names.- R.B.G. Kew.

[6] Catara, S. et al. (2016): Threshold temperatures for seed germination in nine species of Verbascum (Scrophulariaceae) - Seed Science Research 26, 30-46.

[7] Çeçen, Ö., Karavelioğullari, F.A., Ünal, A. (2015): Verbascum misirdalianum (Scrophulariaceae), a new species from central Anatolia, Turkey - Phytotaxa 217 (1): 096-099.

[8] Cenci, C.A., Ceschia, M. (2000): Forecasting of the flowering time for wild species observed at Guidonia, central Italy.- Int J Biometeorol 44:88-96.

[9] Davis, P.H., Mill, R.R., Tan, K. (1988): Verbascum L. - In: Davis, P.H., Mill, R.R., Tan, K. (eds) Flora of Turkey and the East Aegean Islands (suppl.) 10: 191-193., Edinburgh Univ. Press, Edinburgh.

[10] Ekim, T., Koyuncu, M., Vural, M., Duman, H., Aytac, Z., Adiguzel, N. (2000): Red Data Book of Turkish Plants (Pteridophyta and Spermatophyta).- Bariscan Press, Ankara. pp. 246.

[11] Eppich, B. et al. (2009): Climatic Effects on the Phenology of Geophytes - Applied Ecology and Environmental Research 7(3): 253-266.

[12] Ferenczy, A. et al. (2010): Comparative Analysis of the Relationship Between Phenological Phenomena and Meteorological Indicators Based on Insect and Plant Monitoring. - Applied Ecology and Environmental Research 8(4): 367-376.

[13] Gabriele, C. et al. (2014): Climate change hastens the urgency of conservation for rangerestricted plant species in the central-northern Mediterranean region - Biological Conservation 179: 129-138.

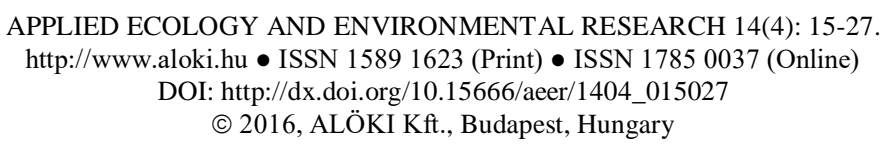


[14] Huber-Morath, A. (1973): Verbascum L. Sl. (İncl. Celsia et Staurophragma Fisch\&Mey) 5(1):11-16. Im Selbstverlag der Basler Botanischen Gesellschaft, Basel.

[15] Huber-Morath, A. (1974): Novitiae Florae Anatolcae XIII 5(1): 14.- Im Selbstverlag der Basler Botanischen Gesellschaft, Basel.

[16] Huber-Morath, A. (1978): Verbascum L. - In: Davis, P.H. (ed.) Flora of The Turkey and the East Aegean Islands. 6:461-603. Edinburg: Edinburgh University Press.

[17] Huber-Morath, A. (1981): Verbascum L. - In: Rechinger, K.H. (ed.) Flora Iranica. 147: 151. Akademische Druck-u Verlagsanstalt, Graz-Austria.

[18] IUCN Species Survival Commission (2001): $51^{\text {st }}$ meeting of the IUCN Concil.- Gland, Switzerland.

[19] Karavelioğulları, F.A., Duran, A., Hamzaoğlu, E. (2004): Verbascum tuna-ekimii (Scrophulariaceae) a new species from Turkey.- Ann. Bot. Fennici 41: 227-231.

[20] Karavelioğulları, F.A., Aytaç, Z. (2008): Revision of the Genus Verbascum L. (Group A) in Turkey.- Botany Research Journal 1 (1): 9-32.

[21] Karavelioğulları, F.A. (2012): Verbascum L. - In: Güner, A., Aslan, S., Ekim, T., Vural, M., Babaç, M.T. (Eds.) Türkiye Bitkileri Listesi (Damarlı Bitkiler). Nezahat Gökyiğit Botanik Bahçesi ve Flora Araştırmaları Derneği Yayını, Istanbul, pp 850-870.

[22] Karavelioğulları, F.A., Yüce, E., Başer, B. (2014a): Verbascum duzgunbabadagensis (Scrophulariaceae), a new species from eastern Anatolia, Turkey. - Phytotaxa 181 (1): 47-53.

[23] Karavelioğulları, F.A., Vural, M., Şahin, B., Aslan, S. (2014b): Iç Anadolu Bölgesi’nden (Türkiye) yeni bir tür: Verbascum aydogdui (Scrophulariaceae) - Karavelioğulları Bilim Dergisi 1 (3): 63-71.

[24] Meikle, R.D. (1985): Flora of Cyprus. 2: 1599-1600.- Kew: Royal Botanic Gardens.

[25] Motamedi, J., Souri, M. (2016): Efficiency of numerical and parametrical indices to determine biodiversity in mountain rangelands - Acta Ecologica Sinica 36: 108-112.

[26] Nagase, A., Dunnett, N., Choi, M.S. (2013): Investigation of weed phenology in an establishing semi-extensive green roof - Ecological Engineering 58: 156- 164.

[27] Parmesan, C., Yohe, G. (2003): A globally coherent fingerprint of climate change impacts across natural systems.- Nature 421:37-42

[28] Peñuelas, J., Filella, I. (2001): Responses to a warming world.- Science 294: 793-795.

[29] Petanidou, T. et al. (2014): Variable flowering phenology and pollinator use in a community suggest future phenological mismatch - Acta Oecologica 59: 104-111.

[30] Schwartz, M.D. (1999): Advancing to full bloom: planning phenological research for the $21^{\text {st }}$ century.- Int J Biometeorol 42:113-118

[31] Sharma, S. (1996): Applied Multivariate Techniques.- John Wiley \& Sons, Inc, New York, USA,493 p.

[32] Sparks, T.H., Jeffree, E.P., Jeffree, C.E. (2000): An examination of the relationship between flowering times and temperature at the national scale using long-term phenological records from the UK.- Int J Biometeorol 44:82-87.

[33] Suchkova, N. et al. (2014): Assessment of phytoremediation potential of native plants during the reclamation of an area affected by sewage sludge - Ecological Engineering 69: $160-169$.

[34] Vural, M., Aydoğdu, M. (1993): A new species from central Anatolia- Verbascum gypsicola (Scrophulariaceae).- The Karaca Arboretum Magazine, 2 (2): 75-78.

[35] Wójcik, M., Sugier, P., Siebielec, G. (2014): Metal accumulation strategies in plants spontaneously inhabiting $\mathrm{Zn}-\mathrm{Pb}$ waste deposits - Science of the Total Environment 487: $313-322$. 